$\xi=\mathrm{\alpha}$

\title{
Allelopathic effects of thuja orientalis L. and melia azedarch L. on seed germination of penisitum americanum $L$
}

\author{
Saeeda Bibi ${ }^{1 *}$, Rukhsana Jabeen ${ }^{2}$, Asma Abdul Hayee ${ }^{2}$, Saima Johar $^{2}$, Shehnaz Sher Ahmed ${ }^{2}$, \\ Shaista Hameed ${ }^{2}$, Mahpara Fida Ahmed ${ }^{2}$ \\ ${ }^{I}$ Department of Plant Sciences, SardarBahadur Khan Women's University, Quetta, Pakistan \\ ${ }^{2}$ Department of Plant Sciences, SBK Women's University Quetta, Pakistan \\ *Corresponding author E-mail:saeeda_botany66@yahoo.com
}

\begin{abstract}
Aqueous extract of leaves, bark and seeds of Meliaazedarach.L and Thujaorientalis L. were assayed at 1,5 and $10 \mathrm{~g} / \mathrm{L}$ concentration with different time period to check their effect on seed germination, fresh and dry weight and seedling growth of Pennesitiumamericanum L. Result revealed that aqueous extracts of both plants at all concentration and time period had significantly inhibited seed germination ofP.ammericanum L. when compared with control. The inhibitory effect increases with increasing concentration of extracts and time period. The bark extract of all concentration of T.orientalis in $24 \mathrm{hr}$ and 48hrs show stimulation in seedling growth while other parts and extracts of all parts of M.azedarachin all concentration and time period show inhibition in all parameters. The order of inhibition when compared different parts of M.azedarch was seeds >bark > leaves while that of T.orientalis was leaves $>$ bark >seeds. Hence it is concluded that aqueous extract of these plant contain water soluble allelochemicals which inhibit the seed germination and seedling growth of P. americanum L. It is suggested that these chemicals may be used as herbicides.
\end{abstract}

Keywords: Meliaazedarach.L; Thujaorientalis.L; Pennesitiumamericanum.L; Aqueous Extract; Seed Germination; Seedling Growth. Fresh and Dry Weight; Allelochemicals.

\section{Introduction}

Allelopathy can be defined as the ability of plant to stimulate or inhibit the growth of other plants in the environment by releasing chemicals or Allelopathy can also be defined as any direct or indirect, beneficial or harmful effects of one plant on other through the production of allelochemicals that it release into the environment [9]. Allelopathy is the relationship between plants by means of allelochemicals released into the environment and exists in natural plant community for long time period and it include both promotion and inhibition [13].All parts of plants such as Leaves, Fruits, Stem, seeds and roots contain allelochemicals which are released into the environment by the process of volatilization, root exudation, leaching and decomposition [12]. These chemicals are known to affect development, reproduction, growth, germination and distribution of a number of plant species [14]. Germination and growth inhibitory effects of plants are associated to allelopathy. Allelopathy plays an important role in agro-ecosystem and natural ecosystem and has both stimulatory and inhibitory effect by releasing allelochemicals into the environment [3].

Meliaazedarach L. is an evergreen tree which belongs to family Meliaceae. It is commonly known as chinaberry tree and closely related to neem.[7] It is one of most important specie because it contains variety of secondary metabolites such as triterpenoids and lemanoids. This plant is widely distributed and moderate sizes deciduous tree with cylindrical bark the leaves are opposite and alternate. This plant is widely used medicinally. [9]
Thujaorientalis belongs to family Cupressaceae. It is monoecious an evergreen tree. This plant contain of phyto constituents such as flavonoids and terpenoids that showed the biological activities [3]. It has great medicinal value. It has antiviral action and immune pharmacological potential [16].

\section{Materials and methods}

\subsection{Extract preparation}

One gram, $5 \mathrm{~g}$ and $10 \mathrm{~g}$ leaves, stems and seeds of Meliaazedarac $\mathrm{L}$. and Juglanregia L. were extracted in $100 \mathrm{ml}$ of distilled water in separate Erlenmeyer flasks $(250 \mathrm{ml})$ for 24,48 and $72 \mathrm{~h}$ at room temperature. The extracts were filtered through ordinary filter papers. The extracts were stored in air tight glass vials and in a fridge at $4^{\circ} \mathrm{C}$ till further analysis.

\subsection{Germination of seeds}

The seeds were germinated on filter paper which was cut in round shape equal to diameter to Petri dish. Twice folded filter paper was placed at the base of Petri dish. Five seeds of P. americanum were placed randomly on filter paper. These Petri dishes were placed in a germinator at $20 \mathrm{C}^{\circ}$ and $20 \%$ humidity. For all the treatments the a biotic factors were same. Three replicates were used for each plant and for each extract. In controlled conditions only distilled water was used. 


\subsection{Measurements of parameters}

To determine the allelopathic effects, seed germination, length of plumule and radical, moisture content of seedlings, fresh and dry weight of seedlings of $P$. americanum were noted against different concentrations of extracts. Readings were taken after 7 day. The length of plumule, radical was measured by scale. The fresh and dry weights of seedlings were taken by digital balance.The germination percentage was also calculated by following formula:

Germination percentage $=\underline{\text { Number of germinated seeds }}$

Total number of seeds $\mathrm{x} 100$

\section{Results}

The present study was conducted to check the allelopathic effect of leaves, stem and seeds on germination rate, fresh and dry weight and seedling growth of pennisitumamericanum. The result were

\subsection{Leaves extract of thujaorientalis $L$.}

Dried leaves of $1 \mathrm{gm}, 5 \mathrm{gm}, 10 \mathrm{gm}$ were soaked for $24,48,72$ hours. These extracts were used for seed treatments. The germination rate of control was $93 \%$. The leaves extract in all concentration and time period show inhibition in germination rate. The fresh and dry weight of control was $0.2 \mathrm{~g}$ and $0.07 \mathrm{~g}$. $1 \mathrm{gm}$ aqueous extract of leaf in $48 \mathrm{hrs}$ and $(5,10 \mathrm{~g})$ in $48 \mathrm{hrs}$ show stimulation in seedling growth and fresh and dry weight. (Table 1.1).

Table 1.1: Effect of Aqueous Leaf Extract of Thujaorientalis on Germination Rate, Fresh and Dry Weight.

\begin{tabular}{lllllll}
\hline $\begin{array}{l}\text { S/n } \\
\text { o }\end{array}$ & $\begin{array}{l}\text { Treat- } \\
\text { ments }\end{array}$ & $\begin{array}{l}\text { Germina- } \\
\text { tion per- } \\
\text { centage } \\
(\%)\end{array}$ & $\begin{array}{l}\text { Fresh } \\
\text { weig } \\
\text { ht }(\mathrm{g})\end{array}$ & $\begin{array}{l}\text { Dry } \\
\text { weig } \\
\text { ht } \\
(\mathrm{g})\end{array}$ & $\begin{array}{l}\text { Seedling growth } \\
\text { Length } \\
\text { of radi- } \\
\text { cal(cm) }\end{array}$ & $\begin{array}{l}\text { Length of } \\
\text { plu- } \\
\text { mule }(\mathrm{cm})\end{array}$ \\
\hline 1. & Control & 93 & 0.2 & 0.07 & $4.5 \pm 0.6$ & $\begin{array}{l}3.19 \pm \\
0.46\end{array}$ \\
2. & 1gm & & & & & \\
& $\begin{array}{l}\text { 24hours } \\
\text { 48hours }\end{array}$ & 40 & 0.07 & 0.03 & $3.2 \pm 2.3$ & $2.2 \pm 0.7$ \\
& 72hours & 60 & 0.27 & 0.19 & $3.2 \pm 2.2$ & $2.1 \pm 0.7$ \\
3. & 5gm & & 0.17 & 0.09 & $3.1 \pm 2.2$ & $2.1 \pm 0.7$ \\
& 24hours & 50 & 0.06 & & $1.4 \pm$ & \\
& 48hours & 47 & 0.25 & 0.03 & 0.36 & $0.3 \pm 0.2$ \\
& 72hours & 47 & 0.11 & 0.06 & $3.2 \pm 2.2$ & $3.3 \pm 1.9$ \\
4. & 10gm & & & & & $1.1 \pm 1.0$ \\
& 24hours & 47 & 0.06 & 0.03 & $2.4 \pm 1.2$ & $0.9 \pm 0.4$ \\
& 48hours & 53 & 0.28 & 0.18 & $6.3 \pm 1.8$ & $4.7 \pm 1.1$ \\
& 72hours & 67 & 0.03 & 0.13 & $4.3 \pm$ & $1.3 \pm 0.2$ \\
\hline
\end{tabular}

\subsection{Aqueous extract of stem}

Aqueous extract of stem in all concentration show inhibition in germination percentage and other parameters but some extract $1 \mathrm{~g}$ in $(24 \mathrm{hr}, 72 \mathrm{hr})$ and $5 \mathrm{~g}$ in $(48 \mathrm{hr})$ show stimulation in seedling growth while other show inhibition in all parameters.( Table 1.2)
Table 1.2: Effect of Aqueous Extract of Stem of T.Orientalis on Seed Germination, Seedling Growth and Fresh and Dry Weight of P. American-

\begin{tabular}{|c|c|c|c|c|c|c|}
\hline \multirow[b]{2}{*}{$\begin{array}{l}\mathrm{S} / \mathrm{n} \\
\mathrm{o}\end{array}$} & \multirow[b]{2}{*}{$\begin{array}{l}\text { Treat- } \\
\text { ments }\end{array}$} & \multirow[b]{2}{*}{$\begin{array}{l}\text { Germina- } \\
\text { tion per- } \\
\text { centage } \\
(\%)\end{array}$} & \multirow[b]{2}{*}{$\begin{array}{l}\text { Fresh } \\
\text { weight(g } \\
\text { m) }\end{array}$} & \multirow[b]{2}{*}{$\begin{array}{l}\text { Dry } \\
\text { weig } \\
\text { ht } \\
(\mathrm{gm})\end{array}$} & \multicolumn{2}{|c|}{ Seedling growth } \\
\hline & & & & & $\begin{array}{l}\text { Lengt } \\
\mathrm{h} \text { of } \\
\text { radi- } \\
\text { cal } \\
(\mathrm{cm})\end{array}$ & $\begin{array}{l}\text { Length } \\
\text { of } \\
\text { plu- } \\
\text { mule } \\
(\mathrm{cm})\end{array}$ \\
\hline 1 & Control & 93 & 0.2 & 0.07 & $\begin{array}{l}4.5 \pm \\
0.6\end{array}$ & $\begin{array}{l}3.19 \pm \\
0.46\end{array}$ \\
\hline \multirow[t]{4}{*}{2} & $1 \mathrm{gm}$ & & & & & \\
\hline & 24hours & 53.3 & 0.14 & 0.033 & $\begin{array}{l}6.618 \\
\pm \\
3.26\end{array}$ & $\begin{array}{l}2.78 \pm \\
2.280\end{array}$ \\
\hline & 48hours & 73 & 0.13 & 0.04 & $\begin{array}{l}3.2 \pm \\
1.4\end{array}$ & $\begin{array}{l}2.3 \pm \\
1.0\end{array}$ \\
\hline & 72hours & 67 & 0.2 & 0.04 & $\begin{array}{l}5.7 \pm \\
4.5\end{array}$ & $\begin{array}{l}0.5 \pm \\
0.4\end{array}$ \\
\hline \multirow[t]{4}{*}{3} & $5 \mathrm{gm}$ & & & & & \\
\hline & 24hours & 60 & 0.14 & 0.04 & $\begin{array}{l}4.1 \pm \\
1.5\end{array}$ & $\begin{array}{l}2.6 \pm \\
0.3\end{array}$ \\
\hline & 48hours & 67 & 0.22 & 0.04 & $\begin{array}{l}5.7 \pm \\
4.5\end{array}$ & $\begin{array}{l}0.5 \pm \\
0.4\end{array}$ \\
\hline & 72hours & 53.3 & 0.06 & 0.02 & $\begin{array}{l}0.8 \pm \\
0.3\end{array}$ & $\begin{array}{l}0.5 \pm \\
0.4\end{array}$ \\
\hline \multirow[t]{4}{*}{4} & $10 \mathrm{gm}$ & & & & & \\
\hline & 24hours & 67 & 0.15 & 0.04 & $\begin{array}{l}3.9 \pm \\
0.6\end{array}$ & $\begin{array}{l}2.5 \pm \\
0.3\end{array}$ \\
\hline & 48hours & 60 & 0.13 & 0.03 & $\begin{array}{l}3.8 \pm \\
0.7\end{array}$ & $\begin{array}{l}1.9 \pm \\
0.2\end{array}$ \\
\hline & 72hours & 30 & 0.05 & 0.01 & $\begin{array}{l}1.8 \pm \\
0.6\end{array}$ & $\begin{array}{l}0.4 \pm \\
0.2\end{array}$ \\
\hline
\end{tabular}

\subsection{Aqueous extracts of seed}

Aqueous extracts of seed also show inhibition in germination rate and other parameters but some extract such as $5 \mathrm{~g}$ and $1 \mathrm{~g}$ in (24hr) show increase in fresh and dry weight while other extract show decrease in fresh and dry weight. $1 \mathrm{~g}$ and $5 \mathrm{~g}$ in $(24 \mathrm{hr}, 72 \mathrm{hrs})$ also show stimulation in seedling growth. (Table 1.3)

Table 1.3: Effect of Aqueous Extract of Seeds of T.Orientalis on Seed Germination, Seedling Growth and Fresh and Dry Weight of P. Americanum.

\begin{tabular}{|c|c|c|c|c|c|c|}
\hline & & & & & Seedlin & growth \\
\hline $\begin{array}{l}\mathrm{S} / \mathrm{n} \\
\mathrm{o}\end{array}$ & $\begin{array}{l}\text { Treat- } \\
\text { ments }\end{array}$ & $\begin{array}{l}\text { Germina- } \\
\text { tion per- } \\
\text { centage } \\
(\%)\end{array}$ & $\begin{array}{l}\text { Fresh } \\
\text { weight(g } \\
\text { m) }\end{array}$ & $\begin{array}{l}\text { Dry } \\
\text { weig } \\
\text { ht } \\
(\mathrm{gm})\end{array}$ & $\begin{array}{l}\text { Lengt } \\
\mathrm{h} \text { of } \\
\text { radi- } \\
\mathrm{cal} \\
(\mathrm{cm})\end{array}$ & $\begin{array}{l}\text { Length } \\
\text { of } \\
\text { plu- } \\
\text { mule } \\
(\mathrm{cm})\end{array}$ \\
\hline 1 & $\begin{array}{l}\text { Control } \\
1 \mathrm{gm}\end{array}$ & 93 & 0.2 & 0.07 & & \\
\hline \multirow[t]{2}{*}{2} & 24hours & 87 & 0.24 & 0.11 & $\begin{array}{l}4.9 \pm 1 . \\
1\end{array}$ & $\begin{array}{l}6.5 \pm 1 \\
6\end{array}$ \\
\hline & 48hours & 53 & 0.14 & 0.03 & $\begin{array}{l}8.0 \pm \\
2.4\end{array}$ & $\begin{array}{l}7.9 \pm \\
5.1\end{array}$ \\
\hline \multirow{5}{*}{3} & 72hours & 40 & 0.09 & 0.04 & $\begin{array}{l}2.6 \pm \\
0.6\end{array}$ & $\begin{array}{l}1.0 \pm \\
0.5\end{array}$ \\
\hline & $5 \mathrm{gm}$ & & & & & \\
\hline & 24hours & 60 & 0.5 & 0.28 & $\begin{array}{l}6.7 \pm \\
0.6\end{array}$ & $\begin{array}{l}9.01 \pm \\
1.1\end{array}$ \\
\hline & 48hours & 60 & 0.2 & 0.1 & $\begin{array}{l}5.2 \pm \\
0.5\end{array}$ & $\begin{array}{l}8.8 \pm \\
2.3\end{array}$ \\
\hline & 72hours & 40 & 0.08 & 0.02 & $\begin{array}{l}2.5 \pm \\
1.5\end{array}$ & $\begin{array}{l}1.3 \pm \\
0.6\end{array}$ \\
\hline \multirow{4}{*}{4} & $10 \mathrm{gm}$ & & & & & \\
\hline & 24hours & 87 & 0.06 & 0.05 & $\begin{array}{l}1.9 \pm \\
0.9\end{array}$ & $\begin{array}{l}1.2 \pm \\
0.8\end{array}$ \\
\hline & 48hours & 73 & 0.11 & 0.05 & $\begin{array}{l}2.5 \pm \\
1.5\end{array}$ & $\begin{array}{l}1.7 \pm \\
0.6\end{array}$ \\
\hline & 72hours & 20 & 0.05 & 0.02 & $\begin{array}{l}0.06 \pm \\
0.00 \\
\end{array}$ & $\begin{array}{l}0.06 \pm \\
0.00 \\
\end{array}$ \\
\hline
\end{tabular}




\subsection{Meliaazedarch L.}

\subsubsection{Aqueous extract of leaves}

The leaves extract of M. azedarch in all concentration in time period of $72 \mathrm{~h}$ showed $0 \%$ germination.while in other time period showed inhibition in all parameters. (Table 1.4)

Table 1.4: Effect of Aqueous Extract of Leaves of M. Azedarch on Seed Germination, Seedling Growth and Fresh and Dry Weight of P. American-

\begin{tabular}{|c|c|c|c|c|c|c|}
\hline \multirow[b]{2}{*}{$\begin{array}{l}\mathrm{s} / \mathrm{n} \\
\mathrm{o}\end{array}$} & \multirow[b]{2}{*}{$\begin{array}{l}\text { Treat- } \\
\text { ments }\end{array}$} & \multirow{2}{*}{$\begin{array}{l}\text { Germi- } \\
\text { natin per- } \\
\text { centage } \\
(\%)\end{array}$} & \multirow{2}{*}{$\begin{array}{l}\text { Fresh } \\
\text { weigh } \\
\text { t } \\
\text { (g) }\end{array}$} & \multirow{2}{*}{$\begin{array}{l}\text { Dry } \\
\text { weigh } \\
\mathrm{t} \\
\text { (g) }\end{array}$} & \multicolumn{2}{|c|}{ Seedling growth } \\
\hline & & & & & $\begin{array}{l}\text { Lengt } \\
\mathrm{h} \text { of } \\
\text { radical }\end{array}$ & $\begin{array}{l}\text { Length } \\
\text { of } \\
\text { plu- } \\
\text { mule }\end{array}$ \\
\hline 1 & Control & 93 & 0.2 & 0.07 & $\begin{array}{l}4.1 \pm \\
1.7\end{array}$ & $\begin{array}{l}1.6 \pm \\
0.2\end{array}$ \\
\hline \multirow[t]{4}{*}{2} & $1 \mathrm{gm}$ & & & & \multirow{4}{*}{$\begin{array}{l}0.6 \pm \\
0.4 \\
1.1 \pm \\
0.1\end{array}$} & \multirow{4}{*}{$\begin{array}{l}0.13 \pm \\
0.02 \\
0.6 \pm \\
0.4\end{array}$} \\
\hline & 24hours & 47 & 0.04 & 0.02 & & \\
\hline & 48hours & 20 & 0.02 & 0.01 & & \\
\hline & $\begin{array}{l}72 \text { hours } \\
5 \mathrm{gm}\end{array}$ & 0 & 0 & 0 & & \\
\hline \multirow{2}{*}{3} & 24hours & 40 & 0.05 & 0.01 & \multirow{3}{*}{$\begin{array}{l}0.2 \pm \\
0.1 \\
0.4 \\
\pm 0.00\end{array}$} & \multirow{3}{*}{$\begin{array}{l}0.1 \pm \\
0.1 \\
0.8 \pm \\
0.7\end{array}$} \\
\hline & 48hours & 27 & 0.04 & 0.01 & & \\
\hline \multirow[t]{4}{*}{4} & $\begin{array}{l}\text { 72hours } \\
10 \mathrm{gm}\end{array}$ & 0 & 0 & 0 & & \\
\hline & 24hours & 7 & 0.02 & 0.01 & \multirow{3}{*}{$\begin{array}{l}0.07 \pm \\
0.03 \\
0.1 \pm \\
0.03\end{array}$} & \multirow{3}{*}{$\begin{array}{l}0.2 \pm \\
0.1 \\
0.3 \pm \\
0.1\end{array}$} \\
\hline & 48hours & 20 & 0.02 & 0.005 & & \\
\hline & 72hours & 0 & 0 & 0 & & \\
\hline
\end{tabular}

\subsubsection{Aqueous extract of stem}

The aqueous extract of M. azedarch.L in all concentration in time period of $72 \mathrm{~h}$ showed $0 \%$ germination.while in other time period showed inhibition in all parameters.( Table 1.5)

Table1.5: Effect of Aqueous Extract of Stem of M. Azedarchon Seed Germination, Seedling Growth and Fresh and Dry Weight of P. American-

\begin{tabular}{|c|c|c|c|c|c|c|}
\hline \multirow[b]{2}{*}{$\begin{array}{l}\mathrm{s} / \mathrm{n} \\
\mathrm{o}\end{array}$} & \multirow[b]{2}{*}{$\begin{array}{l}\text { Treat- } \\
\text { ments }\end{array}$} & \multirow[b]{2}{*}{$\begin{array}{l}\text { Germina- } \\
\text { tion per- } \\
\text { centage } \%\end{array}$} & \multirow[b]{2}{*}{$\begin{array}{l}\text { Fresh } \\
\text { weig } \\
\text { ht }(\mathrm{g})\end{array}$} & \multirow[b]{2}{*}{$\begin{array}{l}\text { Dry } \\
\text { weig } \\
\text { ht }(\mathrm{g})\end{array}$} & \multicolumn{2}{|c|}{ Seedling growth } \\
\hline & & & & & $\begin{array}{l}\text { Length } \\
\text { of radi- } \\
\mathrm{cal}(\mathrm{cm})\end{array}$ & $\begin{array}{l}\text { Length of } \\
\text { plu- } \\
\text { mule }(\mathrm{cm})\end{array}$ \\
\hline 1 & Control & 93 & 0.2 & 0.07 & $4.1 \pm 1.7$ & $1.6 \pm 0.2$ \\
\hline \multirow[t]{4}{*}{2} & $1 \mathrm{gm}$ & & & & & \\
\hline & 24 & 47 & 0.05 & 0.03 & $0.1+0.9$ & $0.5 \pm 0.3$ \\
\hline & 48 & 53.3 & 0.03 & 0.01 & $\begin{array}{l}11.2 \pm \\
1.1\end{array}$ & $0.4 \pm 0.4$ \\
\hline & 72 & 53.3 & 0.1 & 0.1 & $1.7 \pm 0.6$ & $0.5 \pm 0.5$ \\
\hline \multirow[t]{4}{*}{3} & $5 \mathrm{gm}$ & & & & & \\
\hline & 24 & 60 & 0.08 & 0.04 & $0.3 \pm 0.4$ & $0.8 \pm 0.3$ \\
\hline & 48 & 47 & 0.1 & 0.03 & $2.9 \pm 1.0$ & $1.6 \pm 0.4$ \\
\hline & 72 & 40 & 0.06 & 0.03 & $0.8 \pm 0.3$ & $0.5 \pm 0.4$ \\
\hline \multirow[t]{4}{*}{4} & $10 \mathrm{gm}$ & & & & & \\
\hline & 24 & 47 & 0.1 & 0.03 & $0.6 \pm 0.1$ & $0.2 \pm 0.1$ \\
\hline & 48 & 87 & 0.1 & 0.04 & $3.0 \pm 1.2$ & $1.4 \pm 0.9$ \\
\hline & 72 & 0 & 0 & 0 & & \\
\hline
\end{tabular}

\subsubsection{Aqueous extracts of seeds}

The aqueous extracts of seeds of M.azedarach in all concentrations and time period showed $0 \%$ germination.

\section{Discussion}

Allelopathy is the ability of plant to stimulate or inhibit the growth of plants by secreting many chemicals in the environment
[10].The allelopathic potential of aqueous extracts of different parts of both plants at different concentration and time period was evaluated on seed germination percentage, fresh and dry weight and seedling growth of P.ammericanum. All aqueous extract of $\mathrm{M}$. azedarach markedly inhibited all parameters but inhibitory effect increases with increasing concentration and time period. Aqueous extract of seed had more inhibitory effect than other parts when compared. The chemicals which showallelopathic activity are present in different parts of plants including stem, leaves, flowers, seeds and fruits. These chemicals are released into the environment by means of leaching, root exudation, decomposition of residue and volatilization [8].

Aqueous extract of leaves and stem of Calatropisprocera had inhibitory effect on seedling growth, germination and fresh and dry weight ofPennesitunamericanum L. Both plants showed inhibition in seed germination. Meliaazedarach L. showed more inhibition than other plants. Seedling growth is not equally affected by all plants. Thujaorientalis L. in some concentration showed stimulation in seedling growth. Leaves and stem extract of Rhazyastricta also inhabit germination rate and seedling growth of P. americanumL.leaves had more inhibitory effect than stem [5].The aqueous extract of seeds, leaves and stem of Meliaazedarach L.in all concentrations $(1 \mathrm{gm}, 5 \mathrm{gm}, 10 \mathrm{gm})$ showed inhibitory effect on all parameters of Pennisetumamericanum $\mathrm{L}$ which increases with increasing concentration of extract. The order of inhibition was seed $>$ leaves $>$ stem.

Alcoholic and aqueous extract of different parts (fruits, leaves and leaves wood mix) of Meliaazedarach $\mathrm{L}$ reduced seedling growth as well as germination rate of Lectuca sativa. Rate of inhibition varied with extract type and its concentration and order of inhibition was fruit extract> leaves extract> leaves and wood mix extract [7].

Aqueous extracts of seeds of M. azredarachL.showed complete inhibition in all concentrations. The percentage of germination is zero (0) in all concentrations.Inhibitory effect is due to water soluble allelochemicals. The aqueous extract of stem, leaves and seeds of T.orientales $\mathrm{L}$ reduced germination percentage and fresh and dry weight of Pennisetumamericanum L but show stimulation in seedling growth.

Leaves extract of $\mathrm{T}$. orientales $\mathrm{L}$ in all concentrations and stem extract in $48 \mathrm{hrs}$ and $24 \mathrm{hrs}$ showed stimulation in seedling growth.The order of inhibition when compared to different parts of plant was leaves $>$ stem>seeds. $M$.azedarach had more allelopathic effect than T.orientalis L. Results showed that both plants contain allelochemicals which show inhibitory effect against P.ammericanum.

\section{Conclusion}

From the present study it is concluded that Meliaazedarach L. and Thujaorientalis L. have allelochemicals which are secondary metabolites. These chemicals inhibit the seed germination, fresh and dry weight and seedling growth of Pennesitumamericanum L by affecting their respiration, cell division and different metabolic activities. M.azedarach L. has strong allelopathic potential. Plants show inhibitory effect due to water soluble allelochemicals present in their aqueous extracts. It can be used as herbicides for weed management

\section{References}

[1] Alagesaboopathi, C. 2010. Allelopathic effect of Centellaasiatica aqueous extracts on Pearl millet (Pennisetumtyphoides L.) and Cowpea (Vignaunguiculata WALP.). Pak. J. Weed Sci. Res. 16(1): 67-71.

[2] Atallah F. Mekhlif.2009. Effect of Meliaazedarach L. and Ailanthus altissimaSwingle Extracts on the Larva Alimentary Tract and Growth of Black Cutworm, AgrotisipsilonHufn. (Lepidoptera: Noctuidae). J. Raf. Sci., Vol. 20, No.2, pp 8- 18.

[3] Fritz, D. A.P., J.S.Bernardi., B.M. Haas.,S.A.D.L.Ascoli., Bordignon, G.V. Bordignon., Poser.2007. Germination and growth in- 
hibitory effects of Hypericummyrianthum and H.polyanthemum extracts on Lactuca sativa L, Revistabrasileira de Farmacognosia. Brazilian Journal of Pharmacognosy, 17 (1): 44-48.

[4] Hussain,F., B., Ahmed and I, Ilahi. 2010. Allelopathic effects of Cenchrusciliaris L. and Bothriochloapertusa (L.) A.camus. Pak. J. Bot., 42(5): 3587-3604.

[5] Khan, M., Hussain, F., Musharaf, S. (2011). Allelopathic potentia of RhazyastrictaDecne on germination of Pennisetumtyphoides. International Journal of Biosciences (IJB), 1 (4): 80-85.

[6] Isfahan,M.N., M, Shariat .2007. The effect of some allelochemicals on seed germination of Coronillavaria L. seeds. American-Eurasian J. Agric. \& Environ. Sci, 2 (5): 534-538.

[7] Lungu, L., C.L, Popa, J, Morris and M, Savoiu. 2011.Evaluation of phytotoxic activity of Meliaazedarach L. extracts on Lactuca sativa L. Romanian Biotechnological Letters, 16:(2)

[8] Oyun, M.B.2006. Allelopathic potentialities of Gliricidiasepium and Acacia auriculiformis on the germination and seedling Vigour of Maize (Zea mays L.) American journal of agricultural and bio$\begin{array}{lllll}\text { logical } & \text { science } & 1 & \text { (3): }\end{array}$ http://dx.doi.org/10.3844/ajabssp.2006.44.47.

[9] Raja Nagappan.2012. Impact of Meliaazedarach Linn. (Meliaceae) Dry Fruit Extract, Farmyard Manure and Nitrogenous Fertilizer Application against Cabbage Aphid Brevicornyebrassicae Linn (Homoptera: Aphididae) in Home Garden, Asian Journal of Agricultural Sciences 4(3): 193-197.

[10] Siddiqui, S, S Bhardwaj, S.S. Khan and M.K. Meghvanshi.2009. Allelopathic effect of different concentration of water extract of Prosopsisjuliflora leaf on seed germination and radical length of Wheat (Triticumaestivum Var-Lok-1).Ameaican-Eurasion Journal of Scientific research, 4(2): 81-84.

[11] Singh, H.P, R.K,Kohli, D.R., Batish, P.S. Kaushal.1999. Allelopathy of Gymnospermous trees.J.For.Res, (4): 245-254 http://dx.doi.org/10.1007/BF02762256.

[12] Smith, M.W.,M.E., Wolf, B.S., Cheary and M.W. Carroll, Allelopathy of Bermudagrass, Tall Fescue, Redroot pigweed, and Cutleaf evening primrose on Pecan. Hort Science, 36(6):1047-1048.

[13] Samreen, u., Hussain, F., Sher, Z. (2009). Allelopathic potential of Calotropisprocera (AIT.)AIT. Pak. J. Pl. Sci., 15 (1): 7-14.

[14] Tadele,D and D,Teketay.2010. Effects of extracts from leaves of Eucalyptus globulusLabill on seed germination and earl growth of Oleaeuropaea L. subsp. cuspidate.CONFUSE.

[15] Terzi, I.2008. Allelopathic effects of Juglone and decomposed walnut leaf juice on muskmelon and cucumber seed germination and seedling growth. African Journal of Biotechnology Vol. 7 (12), pp. 1870-1874.

[16] Terzi,I and I. Kocaçalıskan.2009. Alleviation of juglone stress by plant growth regulators in germination of cress seeds. Scientific Research and Essay Vol. 4 (5) pp. 436-439.

[17] Wirat Phuwiwat1, Watcharin Wichittrakarn1, Chamroon Laosinwattana1 and Montinee Teerarak1.2012. Inhibitory Effects Of MeliaAzedarach L. Leaf Extracts On Seed Germination And Seedling Growth Of Two Weed Species, Pak. J. Weed Sci. Res., 18: 485-492. 